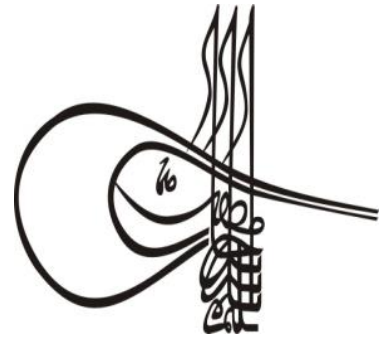

Received/Geliş: 07.08.2019

\section{Tutkigh Studies Historical Analysis}

Volume 14 Issue 3, 2019, p. 553-564

DOI: 10.29228/TurkishStudies.30175

ISSN: 2667-5552

Skopje/MACEDONIA-Ankara/TURKEY

Research Article / Araştırma Makalesi

Article Info/Makale Bilgisi

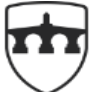

INTERNATIONAL BALKAN UNIVERSITY

EXCELLENCE FOR THE FUTURE IBU.EDU.MK

\Accepted/Kabul: 10.09.2019

Gor Report Dates/Rapor Tarihleri: Referee 1 (17.08.2019)-Referee 2 (19.08.2019)

This article was checked by intihal.net.

\title{
OSMANLI DONANMASININDA GÜVERTECİLER İÇİN HAZIRLANAN KURS PROGRAMLARI
}

\author{
Derya GEÇILI I*
}

\begin{abstract}
öz
Gemiler oldukça karmaşık araçlardır, sürekli ama yavaş yavaș gelişirler. Avrupa devletlerinin deniz politikalarına, stratejik ve teknolojik tercihlerine göre gemilerin inşasında yenilikler olmuştur. Osmanlı Devleti, 1770 senesinde büyük Çeşme faciasından sonra bilim ve teknoloji yönünden Avrupa'dan geri kaldığını fark etmiştir. Denizlerde Batılı devletlerle rekabet edebilecek bir seviyeye gelebilmek için Avrupa'daki gelişmelerin takip edilmesi gerekiyordu. Bu amaçla, Avrupa usullerine uygun gemiler inşa edilerek Türk savaş filoları yeni baştan meydana getirilmeye çalışılmıştır. Aynı zamanda bu gemileri bilinçli bir şekilde yönetecek, kullanabilecek iyi öğrenim ve eğitim görmüş personele de ihtiyaç olduğu gözden kaçırılmamış ve Bahriye Mektebi açılmıştır. Bahriye Mektebinde sınıflar zamanla çeşitli bölümlere ayrılarak alanına göre eğitim verilmiștir. Her biri büyük öneme sahip bu bölümlerden biri de gemilerde ağır donanım işlerini yapan Güverte mühendisleridir. Güverteciler, gemilerin işleyiş ve hareketlerinde önemli role sahip oldukları için uzun süre zarfinda teorik ders, kazan, makine ve fener kullanımlarında yetiştirilmişlerdir. Güverteciler, üçüncü sınıfta önce talim gemilerine ardından kurslara gönderilerek görevlerini tam olarak anlamalarına çalışılmıştır. Güvertecilere kurslarda verilecek eğitimle ilgili ders programları hazırlanarak uygulamaya konulmusstur. Kurslarda başarılı olan güverte mühendisleri Mülazım-1 sani olarak göreve başlamışlardır. Güvertecilerin yetiștirilmesine dikkat edilerek hem batı ile rekabet edebilecek bir seviyeye ulaşılacağı hem de denizlerde meydana gelebilecek kazaların önüne geçilebileceği düşünülmüştür.
\end{abstract}

Anahtar Kelimeler: Donanma, Güverte, Kurs, Eğitim. 


\title{
COURSE PROGRAMS PREPARED FOR DECK BOYS IN OTTOMAN NAVY
}

\begin{abstract}
Ships are very complex vehicles, but they develop slowly but continuously. There have been innovations in the construction of ships according to the European policies, strategic and technological preferences. After 1770 Çeşme disaster, the Ottoman Empire realized that it remained backward from Europe in terms of science and technology. From then on, work was undertaken to modernize the navy in order to enable the Ottoman State to compete with Western powers in the seas. Ships suitable for European procedures have been constructed and Turkish war squadrons have been tried to be rebuilt. At the same time, it was not overlooked that there was a need for well-educated and trained staff to manage and use these ships consciously. In the Naval School, the classes were divided into various sections over time and trained according to the field. Each one of these parts is of great importance, and one of them is deck boys who are doing heavy equipment works. Deck students have been trained in theoretical courses, boilers, machinery and lanterns in a long time because they have an important role in the operation and movements of ships. Deck Engineers were first sent to training ships and then to courses in the third grade to make them fully understand their duties. It was thought that the accidents in the seas would be avoided and also it would be possible to compete with the West in maritime by educating naval deck boys attentively. Below are the training and course schedules given in the courses during the training of the deck boys.
\end{abstract}

\section{STRUCTURED ABSTRACT}

Despite all the known or unknown dangers of the sea, sea travel and naval trade have always been considered to be cheaper and easier compared to the travel and trade on land. The maritime transport was carried out with boats, "peremes" and barges in the Ottoman Empire in the $15^{\text {th }}, 16^{\text {th }}$, and $17^{\text {th }}$ Centuries. There have been innovations in the construction of ships according to the European policies, strategic and technological preferences. After 1770 Çeşme disaster, the Ottoman Empire realized that it remained backward from Europe in terms of science and technology. Ships suitable for European procedures have been constructed and Turkish war squadrons have been tried to be rebuilt. At the same time, it was not overlooked that there was a need for well-educated and trained staff to manage and use these ships consciously. To cover this need, and to bring the maritime affairs to compete with those in Europe, the Naval School was opened. In the Naval School, the classes were divided into various sections over time and trained according to the field. Each one of these parts is of great importance, and one of them is deck boys who are doing heavy equipment works. For the ships to be enabled to travel safely and with care, the attendant on the decks had important duties. In addition, it was not possible to close this gap by outsourcing qualified staff for an important task like this. At first, the gap in this field was covered with foreign experts and engineers. However, they were not adequate for the ships because they required high payments, and their number was not adequate. With the effect of these problems that stemmed from the lack 
of the deck attendants, "Deck Departments" were opened, and the staff requirements of the ships were covered in this way. Deck students were trained in theoretical courses, boilers, machinery and lanterns in a long time because they have an important role in the operation and movements of ships. Deck Engineers were first sent to training ships and then to courses in the third grade to make them fully understand their duties. Below are the training and course schedules given in the courses during the training of the deck boys. In these courses, the deck boys had the opportunity to learn their profession fully and had the knowledge on the coasts and ports of the Ottoman Empire and of many foreign states. The most important of these courses that were opened for deck boys were for canons and torpedoes. The students who completed the torpedo courses were sent to the artillery and infantry courses; and those who completed the artillery courses were sent to the infantry courses. The artillery courses were provided at the artillery school ship, the Torpedo Course was provided at the torpedo school ship; and the Infantry Courses were provided at the barracks. Great attention was paid to the training of the deck boys as much as the courses and the discipline and training. One teacher (engineer officer) was appointed for each course, and was held responsible for the training of fifteen deck boys. The deck boys were under the command and control of their specially-appointed teachers. In addition, the same teachers were appointed in the courses, and the deck boys were made to meet and learn from experienced officers.

There were two artillery courses in the artillery school ship. The purpose of these courses was to enable the students to understand the fundamentals of artillery especially in a practical way. The preparation and management of the training programs in the artillery courses was carried out in the same way as in the torpedo courses. The subjects that were taught in the Naval School were also repeated in the artillery courses. General information was given to the students on the methods of attack and defense with canons, and how to use them on the ships. Two torpedo courses were provided on the torpedo school ship, nine weeks each. The purpose of these courses was to enable the engineers to acquire skills by working directly on how the torpedo was employed, on its characteristics, and how the torpedoes were managed. The subjects were repeated continuously to ensure that the students could understand their duties well.

Two Infantry Service Courses were provided each year as for four weeks each in the barracks. When the deck students were in the barracks, the deck students participated in the marches with the officers. At the end of the training that was provided in the Infantry Course, the deck students were tested on the subjects given in the course. Only the artillery and torpedo were accepted as the first degree courses, and infantry service was accepted as the second degree courses. In these courses, great attention was paid to the training of the deck students on the use of torpedoes that were newly purchased by the Ottoman Empire. Technical information was given in these courses on torpedoes, especially in practice. The students who succeeded at the end of these trainings were given ranks and seniority rises. Warships, which played very important roles for the Ottoman State, began to be used safely by the deck attendants who were specially trained in this field.

Keywords: Navy, Deck, Course, Training. 


\section{Giriş}

Osmanlı donanmasının 1770'de Çeşme'de uğradığı yenilgi, İnebahtı deniz savaşından sonra görülen ikinci büyük felaket oldu. Baltık'tan hareket eden Rus donanması, İngiliz ve Danimarkalı denizcilerin kumandası altında Akdeniz'e gelmişlerdi. Osmanlı donanmasını Çeşme'de yakmak suretiyle imha etmeleri, Osmanlı devlet adamları üzerinde donanmanın modernleşmesi gerektiği konusunda uyarıcı bir rol oynamıştır. Bu modern gemilerde denizcilerin sorumluluk almadan önce iyi bir eğitime tabi tutulmalarına karar verildi. III. Mustafa zamanında İlk kez 1773 yılında Kasımpaşa'nın Darağacı semtinde "Hendesehane" adıyla açılan mühendishane, 1774'de fiilen öğretime geçmiştir. Okulun öğretim görevlilerini Baron de tott ile yardımcı olan Fransız mültecilerinden Kermorvan İngiliz dönmesi Kampel Mustafa Ağa ve birkaç arkadaşı meydana getirmişlerdi. Öğrenciler okulda üç ay içinde düzlem geometrinin dört kuralı arazi üzerinde uygulayabilecek bir duruma gelmişler ve öğretim çalışmaları bu noktadan ileri gitmemişti. Çünkü okulun açılış amacı yükselti almasını kroki çizmesini ve gemi rotasının hesaplanmasını ve belirlenmesini bilen kara ve deniz mühendisleri yetiştirmek üzere planlandığından altmış yaşlarındaki öğrencilere bu kadar bilgi yeterli görülmüştü. Bu açıklamalara göre okul bilgi tamamlama ve yetiştirme kursu kimliğinde geçici nitelikte olmuştur. Buna benzer bir kurs daha sonraları Kaptan-1 Derya Küçük Hüseyin paşanın 26 Ocak 1797 tarihinde hendeshanenin seyr-i sefain kısmında açılmıştı. Ayrıca donanma hocalarının denizcilik tekniğini öğrenmek için kurs almaları ve bunlara donanma subaylarından öğretim görmüş olanlarının öğretmenlik yapmaları gemi hocalarına kaptane kalyonunun hocalarının nezaret edeceği kabul edilmiştir. 1776'da yılında Kaptan-1 derya Cezayirli Gazi Hasan Paşa tarafından kalyonlarda hendese ve coğrafya bilimlerinden anlayan subaylar yetiştirmek amacı ile Haliç'te Tersane-i Amire'nin Darağacı semtinde bir hendese odası yapılmıştı. Daha sonra III. Selim tarafından 1793 yılında deniz okulları yeniden düzenlenmiş; 1806'da Mühendishane-i Bahri-i Hümayun adıyla devam etmiştir. (GÜLEN, Şanlı Bahriye, 2001)

Sultan Abdüllaziz döneminde ise 1870 yılında Heybeliada'daki mektebin içinde yatılı olmak üzere Bahriye Mektebi açılmıştı. Bahriye Mektebinde sınıflar zamanla bölümlere ayrılarak alanına göre eğitim verilmeye başland. Her biri büyük öneme sahip bu bölümlerden biri de Güverte Mektebi olmuştur. Güvertecilerin yetiştirilebilmesi için muallimler dikkatli bir şekilde seçilerek kontrole tabi tutulurdu. Mektebe kabul edilecek öğrencilerin bazı şartları taşımaları zorunlu olurdu. Özellikle, güvertecilerin mesleklerini tam olarak icra edebilmeleri için sağlık kurallarına uygun olmalılardı. Öğrencilerin bu özellikleri taşımadıkları düşünülürse hemen mektepten ihraç ediliyorlardı. Mektebe kabul edilen öğrenciler önce hazırlık sınıflarında eğitim alır, ardından sınava tabi tutulurlardı. Bu sınavda başarılı olanlar güverte öğrencisi olarak okula kabul ediliyordu. Mektepte, öğrencilerin eğitimleri sadece teorik değildi. (GÖKÇAY, Deniz İkmal Eğitimi ve Okulları (1699-1999)) Talim gemileri ile uygulamalı eğitim de verilirdi. Böylece, öğrencilerin bir gemicinin karşılaşabileceği durumları yaşayarak öğrenmesi sağlanırdı. Mektepte öğrenciler, eğitimleri sırasında veya sonunda Avrupa'ya gönderilmeye başlanmıştı. Öğrencilerin yurtdışında aldıkları eğitimle denizcilik ve gemilerin işleyişi sahasındaki gelişmeleri takip edebilmeleri amaçlanmıştı. Güverte Mektebi'nde eğitimini tamamlayanlar, donanmaya deniz mühendisi olarak kabul ediliyordu. Mühendislerin uygun bir kadroyla donanmaya yerleştirilebilmeleri için "Mülâzım-1 sânilik" rütbesini almaları zorunlu olmuştu. Mülazımlara talim gemilerinin mümkün mertebe birçok mevkilerinde sorumluluk verilerek mektepte aldıkları eğitimi anlamalarına çalışılırdı. Mülazımların gösterilen dersleri öğrendiklerini ve mesleklerinde başarılı olacaklarını ispat etmeleri gerekiyordu. Mülâzımlar, dört sene sonunda bir sınava tabi tutularak başarılı olurlarsa subay olarak kabul edilmişlerdir. (DMA, III.Daire, 30/8, 1913) Osmanlı donanmasında göreve başlayan subayların zırhlı, dretnot, kompazayt, denizaltı ve kruvazör, torpidobotların silah, makine ve diğer özellikleri hakkında son derece başarılı ve bilgi sahibi olmalarının yolları aranmıştır. Böylece, deniz subaylarının savaş gemilerinde görecekleri ve kullanacakları araçgereçlerle ilgili mekteplere bağlı olarak ve Bahriye Nezaretinin kontrolü altında kurslar açılmıştır. İlk kurs sadece İngilizce ve Fransızca eğitim şubelerinden oluşmuş, bir süre sonra ise meslek kursları olarak 
devam etmiştir. Bu kurslarda verilen eğitiminin her hangi birinde başarı kazanarak başka bir kursa devam edenlere, mütehassıslık (uzman) unvanı verilmiştir. Böylece, hem donanma için yeterli bilgiye sahip uzman subaylar yetiştirilmiş hem de subayların eğitimlerinin mükemmel olması sağlanarak rütbelerine kıdem zammı gibi mükâfatlardan istifade etmeleri sağlanmıştır. Güvertecilerin rütbe almaları ve bilgilerini genişletmek amacıyla zamanla kurslar açılarak başarılı olanlar yüzbaşı olarak atanmaya başlamıştır. (BOA, BD.R, 118/12)

\subsection{Güverte Mektebi'ne Öğrencilerin Kabul Edilmeleri}

Güverte Mektebi'ne kabul edilecek öğrencilerin sayısı Bahriye Nezareti tarafından belirlenerek Haziran ayında gazetelerde ilan edilirdi. Taliplerin Temmuz ayının ortalarına kadar Bahriye Nezaretine bir dilekçe ile başvuru yapmaları gerekiyordu. Talipler, Ağustos ayında ilan edilen gün ve saatte fiziki ve ruhi yapılarının güvertecilik için yeterli olduğunu sağlık heyetine ispat ediyorlardı. (Bahriye Güverte Zabitanının Suret-i Duhul ve Tahsili Hakkında Nizamname, 1917: 2) Talipler arasında göze çarpacak bir hastalığ olmayanlar hemen elenirdi. Buna göre; güvertecilerin dededen Osmanlı tebaası ve Müslüman olmaları şarttı. Hıristiyan veya Museviler, mektebe kabul edilmiyorlardı. Hazırlık ve birinci sınıf öğrencisinin 14 yaşından küçük ve 15 yaşına girmemiş olması zorunluydu. Yaş için yalnız yazılı vesika esas alınmazdı. (Güverte Mühendislerinin Kurslarda Donanmada Tahsilleri Hakkında Talimatname, 1917: 3) Aynı zamanda talibin vücudunun hali ve akli durumunun da o yaşta görünmesine dikkat edilirdi. Taliplerin, ibtidâi veya sultani mekteplerinden başarıyla mezun olması gerekirdi. Her talibin sağlı̆̆ıyla ilgili olarak bedeninde noksanlık, dilinde kekemelik, işitme sorunu, renk körlüğü doğum öncesi ya da sonrasında herhangi bir hastalığa meyli ve hiçbir zayıflığı olmamalıydı. (DMA, BN, 534/257) Ayrıca, her hususta yaşıyla uygun bir derecede büyümüş olması şarttı. Bu muayene de özellikle deniz hayatının zorluk ve zahmetlerine tahammül edebilecek öğrencilerin seçilmesine çalışılmıştı. Sağlık heyetinin karşısında mesleğe uygun olduklarını kanıtlarlarsa mektebe kabul edilirlerdi. Muayene ve imtihana kabul edilmeyenlerin soru sorma ve itiraz hakları olmuyordu. Öğrencilerin gerek mektepte ve gerekse talim gemisindeki masrafları hükümet tarafından karşılanırdı. (DMA, BN, 534/257) Ayrıca, mühendis olana kadar her sene ceket, pantolon, ayakkabı ve iki senede bir çuha kaput (üstlük elbise, yağmurluk) verilirdi. Sadece, eğitim süresi boyunca müfredata göre karar verilen elbise gibi masrafları, veliler karşılamak zorundalardı. Güverteciler, hazırlık sınıfları dışında; dört sene Bahriye Mektebi'nde (öğrenci), bir buçuk sene seyyar talim gemisinde (denizci) iki buçuk senede Bahriye Mektebinin dördüncü sınıfı ile kurslarda (mühendis) eğitim alarak tahsillerini tamamlıyorlardı. (Güverte Deniz Öğrencisinin Talim Gemisinde Eğitimleri Hakkında Talimatname, 1914: 3) Öğrencilerin eğitim programları, zaman zaman değişikliklere ve yeniliklere tabi tutularak Bahriye Nezareti tarafindan risale şeklinde yayınlanırdı. Mektepte ders yılı Eylül'de başlar Haziran ayında biterdi. Birinci dönem sınavları, Aralık ve ikinci dönem sınavları Mart ayı içinde olurdu. Sınavlarında başarılı olamayan öğrenciler, iki sınıfın derslerinden bir senelik ders döneminde sınav yapılmazdı. Birinci ve ikinci dönem sınavlarının sonunda birer hafta, üçüncü dönem sınavlarının sonunda ise öğrenciye sekiz hafta izin verilirdi. Bir senelik ders dönemlerinde farklı mazeretlerle okula neredeyse üç aya yakın devam etmeyen öğrencinin bir sonraki sene devam etmek üzere geçici olarak kaydı silinir ve ikinci senesinde de devam etmez ise okuldan ihraç edilirdi. (DMA, MB, 517/249, 1918)) Bir dönem boyunca muhtelif günlerde çeşitli mazeretlerle okula bir aya yakın devam etmeyen öğrenci ise o dönem sinavlarına alınmaz, bir senelik ders dönemi zarfinda üçer ay ara ile üç ders döneminden sınav yapılırdı. Birinci ve ikinci ders dönemi imtihanlarında kazanılan numaralar, üçüncü dönem sınav notu verilirken nazar-ı dikkate alınırdı. Birinci ve ikinci sınıf öğrencileri, okul tatilinin sonunda ikmal sınavı yapılırdı. Yüksek sınıflarda bulunan öğrencilerin ikmal sınavı olmazdı. (DMA, BN, 85/171, 1916) İkmal sınavında yeterli not alamayan öğrenci, üst sınıfa geçemiyordu. Sınavların sonunda verilen hüküm, öğrencinin mektebe başarıyla devam edip etmediğini gösterirdi. Veliler, okul tarafından verilen kitap, eşya, elbise ve diğer malzemelerin masrafını ödemekle yükümlü olmuşlardı. Sebebi ne olursa olsun okuldan ayrılan 
öğrencilerden, eğitim sırasında yapılan masraflar için senelik elli Osmanlı Lirası alınırdı. Ancak öğrenci, okul tarafından ihraç edilirse her hangi bir ücret talep edilmezdi. Öğrenciler, üçüncü sınıf olduklarında talim gemilerine gönderilirdi. Bu nedenle üçüncü sınıf sınavlarında okulda gösterilen dersleri öğrendiklerini ve talim gemisindeki talim ve terbiyede başarılı olacaklarını ispat etmek zorundalardı. Talim gemisinde bulundukları süre zarfında kendilerine eğitimi verilen konuların ders programları talimatnameye bağlı olurdu. (DMA, BN, 61/1291) Talim gemisinde başarılı olan mühendisler, Bahriye Mektebinin dördüncü sınıfına geçiyorlardı. Güverte Mektebinde dördüncü sınıf mühendislerinin mektep talimatnamesinin bazı maddelerine uygun hareket etmeleri gerekiyordu. Subay derecesinde bulunduklarından kendilerine diğer öğrencilerden daha fazla serbestlik verilir, izinleri de haftada bir defaya çıkarılırdı. Güverteci mühendislere eğitimin sonunda güverteci şehâdetnâmesinden (diploma) başka hizmeti hakkında bir hüküm verilirdi. Bu hükümde güvertecinin ahlaki ve fikri vasıfları ile mesleğe ve hizmete olan fedakârlığı da dâhil edilirdi. (DMA, MB, 57/89)

\subsection{Güvertecilerin Kurslara Gönderilmeleri}

Güverteci mühendisler, eğitim ve öğretimlerini tamamlamak için kurslara gönderilirdi. Kurslarda verilen eğitimle güvertecilerin hem mesleklerini tam olarak öğrenebilmelerine hem de Osmanlı Devleti ile yabancı devletlere ait sahil ve limanlar hakkında bilgi sahibi olabilmelerine çalış1ırdı. Bu kursların en önemlileri top ve torpido kursu olmuştu. Torpido kursunu tamamlayanlar piyade kursuna, topçu kursuna ve topçu kursunu tamamlayanlar ise piyade kursuna gidiyorlardı. (DMA, BN, 61/1291) Bu kurslar, Mart ayında başlar ve Eylül ayında tamamlanırdı. Topçuluk kursu on iki, torpido kursu dokuz, piyade kursu dört hafta devam ederdi. Topçuluk kursu, topçu mektep gemisinde, torpido kursu, torpido mektep gemisinde ve piyade kursu ise kışlada verilirdi. Gemilerde güvertecilere mümkün mertebe kendi alanlarıyla ilgili doğrudan eğitim verilerek, gemi ve deniz konularını tam olarak anlayabilmeleri sağlanırdı. Güvertecilerin kurslarda eğitimleri kadar disiplin içinde olmalarına ve terbiyelerine de büyük özen gösterilmiştir. Her bir kurs için bir muallim (mühendis subay) görevlendirilerek on beş mühendise ders verilirdi. Mühendisler, özel olarak görevlendirilen muallimin emri ve kontrolü altında bulunurlardı. Muallimler, kursun adeta müdürü ve uzmanı olur, aynı zamanda mühendislerin emir ve idarelerini kontrol ederlerdi. Muallimler, mühendislerin tahsil ve terbiyelerinden, onların görev sırasında ve dışındaki hareketlerinden topçu mektep gemisi süvarisine karşı sorumlu oluyorlardı. Ayrıca, kurslarda sürekli aynı muallimler görevlendirilerek mühendislerin tecrübeli subaylarla görüşmelerine çalışılırdı. (Güverte Mühendislerinin Kurslarda Donanmada Tahsilleri Hakkında Talimatname, 1917: 4)

Resim 1. Talim Gemisi (DMA, M.M, 55/31-1)

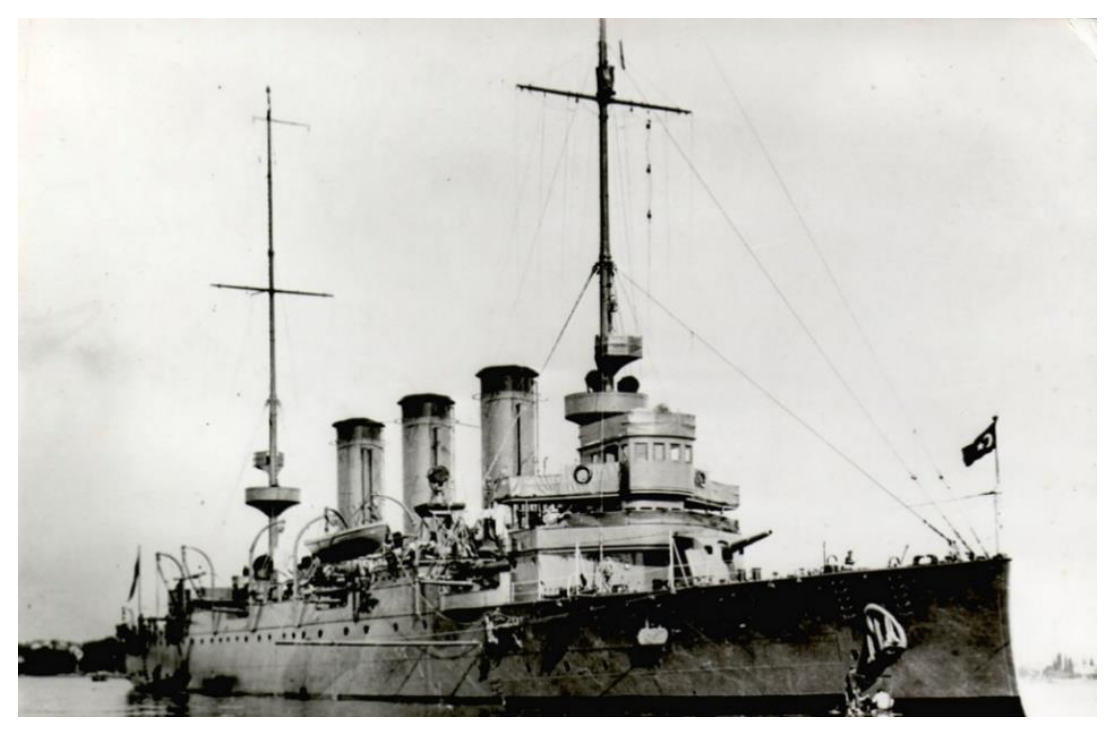

Turkish Studies - Historical Analysis

Volume 14 Issue 3, 2019 


\section{Topçu Kursu}

Topçu mektep gemisinde iki topçuluk kursu olurdu. Bu kursların amacı mühendislerin topçuluğun esaslarını özellikle uygulamalı bir şekilde anlamalarını sağlamaktı. Topçuluk kurslarında eğitimin tanzim ve idaresi torpido kursu ile aynı şekilde yapılırdı. Bu kursta mühendisler, grup kumandanı olmak üzere talim ve terbiye edilerek savaşta birçok küçük ve büyük çapta topların idaresi konusunda yetiştirilmişti. Mühendislerin gerek Osmanlı donanmasında ve gerekse yabancı devletlerin sahil istihkâmlarındaki topları görerek mühimmat depolarını incelemelerine çalışılırdı.

Topçuluk kursunda Bahriye Mektebinde öğretilen konuların tekrarı da yapılırdı. Top ile saldırı ve savunma şekilleri ile topların gemilerde kullanılma usulü hakkında genel bilgi verilirdi. Dâhili balistik, barut, cephane, geminin zırh aksamı; cephaneler, mermilerin tesirleri ve kuvvetleri, makineli toplar, büyük ve küçük top kundakları ile teleskoplarının imal edilme usulü, sahil istihkâmları, cephane ambarları, top fabrikası, Osmanlı ve yabancı devletlerin topları ile özellikleri gösterilerek kabiliyet kazanmalarına çalışılırdı. Ayrıca, bir geminin çeşitli seri ateşli ve maksim toplarıyla saldırı usulleri ile ilgili talimler yaptırılarak cephanenin idaresi, kullanımı ve muhafazasına dair ve mesafe tahmini hakkında eğitim verilirdi. (Bu konuların nasıl öğretileceğine talim gemisinin topçu subayı karar verirdi)

\section{Torpido kursu}

Her biri dokuz hafta olmak üzere torpido mektep gemisinde iki torpido kursu verilirdi. $\mathrm{Bu}$ kursun amacı, torpido subayı olabilmeleri için mühendislere torpidonun kullanılma usulü, özellikleri ve torpidobotların nasıl idare edildiği hakkında doğrudan çalışarak maharet kazanmalarını sağlamaktı. Mühendislerin görevlerini iyi anlayabilmeleri için torpidoya dair konular sürekli tekrar edilirdi. (DMA, BN, 55/1053: 1918)

Mühendisler, torpido eğitim programına göre gemideki torpido modellerinde göre ders görürken aynı zamanda yutup modellerini öğrenirlerdi. (DMA, BN, 65/1291) Mühendisler için torpido kursunda; torpidobotların maksat ve kullanımları, denizaltı ve tayyarelerdeki torpido silahları, torpidobot teşkilatı, torpidobot hücumunun nazariyatı, torpido subaylarının görevleri, savaş olması muhtemel devletlere ait torpido ve torpidobotlar, gemi ve torpidobotlarla gündüz saldırısı, gece saldırıs1, Şivarskof Torpidosunun özellikleri, yutubların idare ve kullanımı, torpidoyu yutuba sürmek ve çıkarmak, torpido ve eklentilerinde kullanılan bütün cephaneler, hava tulumbaları, torpido defterleri ve günlük yazılan raporlar, karada ve denizde dinamit kullanmak, torpidoların endahttan önce ve sonra idare usulü, endaht sırasında torpido üzerinde yapılacak tedbirler hakkında malumat, torpido endahtı hakkında kayıt tutmak, kayıt defterleri hakkında malumat, belirli bir hedefe ateş etmek, torpido atıldıktan sonra tekrar gemiye almak için gönderilen istimbottaki görevler, torpidonun bir mahalden başka bir mahale nakli, endaht edilen torpidonun gözlemlenmesi ve yakalanması, yabancı torpidoların belirlenen mesafeyi tecavüz ederek istikametinden çıkması halinde alınması gereken tedbirler hakkında eğitim verilirdi. Ayrıca, bir torpidobot nöbetçi subayının görevleri öğretilerek, torpido hücumları sırasında geminin seyir durumu, dümencilik, makine telgrafçılığı, torpidobotun idaresi, yanaşması ve uzaklaşması, demirlemesi, filotilla ile seyir, işaret, aynı zamanda bulma talimleri, torpidoya ait bütün vaçbil talimleri yaptırılırdı. (DMA, BN, 236/4487) 


\begin{tabular}{|c|c|c|c|c|c|c|}
\hline \multicolumn{7}{|c|}{ Tablo 1: Torpido Birinci Kursu Haftalık Görev Programı } \\
\hline & Cumartesi & Pazar & Pazartesi & Sal1 & Çarşamba & Perşembe \\
\hline 09.00-10.00 & $\begin{array}{l}\text { Torpidobot } \\
\text { veya Gemi }\end{array}$ & $\begin{array}{c}\text { Eğitim } \\
\text { Programına } \\
\text { Göre Vazife }\end{array}$ & İşaret Dersi & $\begin{array}{c}\text { Eğitim } \\
\text { Programına } \\
\text { Göre Vazife }\end{array}$ & $\begin{array}{c}\text { Eğitim } \\
\text { Programına } \\
\text { Göre Vazife }\end{array}$ & $\begin{array}{l}\text { Çamaşır } \\
\text { Yıkama }\end{array}$ \\
\hline $10.10-10.20$ & Paydos & Paydos & Paydos & Paydos & Paydos & Banyo \\
\hline $\begin{array}{l}10.20- \\
11-30 \\
\end{array}$ & $\begin{array}{l}\text { Torpido veya } \\
\text { Gemi Talimi }\end{array}$ & $\begin{array}{c}\text { Torpidobot } \\
\text { veya Gemide } \\
\text { Talim } \\
\end{array}$ & $\begin{array}{c}\text { Eğitim Programına } \\
\text { Göre Vazife }\end{array}$ & $\begin{array}{c}\text { Torpidobot } \\
\text { veya Gemide } \\
\text { Talim } \\
\end{array}$ & $\begin{array}{l}\text { Torpidobotta } \\
\text { Talim } \\
\end{array}$ & Temizlik \\
\hline $13.30-15.00$ & $\begin{array}{l}\text { Askeri Görev } \\
\text { Dersi }\end{array}$ & $\begin{array}{l}\text { Askeri Görev } \\
\text { Dersi }\end{array}$ & $\begin{array}{l}\text { Kürek Talimi, } \\
\text { Beden Eğitimi }\end{array}$ & $\begin{array}{l}\text { Askeri Görev } \\
\text { Dersi }\end{array}$ & $\begin{array}{l}\text { Askeri Görev } \\
\text { Dersi }\end{array}$ & \\
\hline $15.00-15.15$ & Paydos & Paydos & Paydos & Paydos & Paydos & \\
\hline $15.15-16.30$ & $\begin{array}{c}\text { Torpidobotlarda } \\
\text { Ameli Ders } \\
\end{array}$ & $\begin{array}{c}\text { Torpidobotlarda } \\
\text { Ameli Ders } \\
\end{array}$ & $\begin{array}{c}\text { Eğitim Programına } \\
\text { Göre Vazife }\end{array}$ & İşaret Dersi & $\begin{array}{l}\text { Piyade } \\
\text { Talimi }\end{array}$ & \\
\hline $20.30-21.30$ & & & & & Gece İşareti & \\
\hline
\end{tabular}

\section{Piyade Hizmeti}

Piyade kurs programının amacı bir mühendisi takım zabiti olarak yetiştirmekti. Her biri dört hafta olmak üzere kışlada her sene iki piyade hizmeti kursu verilirdi. Piyade hizmetinde talim için daha önce kursa gitmiş bir kıdemli yüzbaşı görevlendirilirdi. Bu yüzbaşı aynı zamanda mühendis olmak zorundaydı. Piyade kursunun eğitim ve talim programı yüzbaşı tarafından hazırlanır ve kışla kumandanı tarafından kontrol edilerek uygulamaya geçilirdi. Mühendisler, kışla veya diğer uygun yerlerde ayrı olarak iskân edilirdi. Her dört mühendis için bir görevli bulunurdu. Mühendisler, kışlada bulundukları sırada memur ve subaylarla birlikte yürüyüşlere katılırlardı. Piyade kursunda eğitim ve talimin sonunda mühendisler, ders konularıyla ilgili sınavdan geçilirdi, sadece topçuluk ve torpido birinci derece ve piyade hizmeti ise ikinci derece ders olarak kabul edilmişti.

Piyade kursunda mühendisler, yürüyüş hattının birinci ve ikinci kollarındaki subayların görevleri, ileri karakol vazifesi, tecavüzde düşmana hücum eden bir manga takımına kumanda ve müdafaa eden subayların görevlerini öğreneceklerdi. Savaşta ateş idaresini mesafe tahmilini, istihkâm vazifesini anlayacaklardı. Talimler, bir askerin yetiştirilmesi bir sıranın talimi (yürüyüş ve silah harekâtı, dönüşlere kumanda verebilmek) bir takımın talim ve idaresi ile bütün bu harekât piyade talimnamesine göre yapılırdı. Mühendisler manga halinde bizzat saldırı yapacak ve böyle bir mangaya talimnameye göre kumanda etmesini öğreneceklerdi. Gerekirse ara sıra Maltepe Endaht Mektebine giderek oradaki endahtları göreceklerdi. Piyade talimi, jimnastik, kürek çekmek, işaret dersi alacaklardı. Dersler, müşavir ve muavin tarafından bizzat gösterilirdi. (Bahriye Güverte Zabitanının Suret-i Duhul ve Tahsili Hakkında Nizamname, 1917: 6)

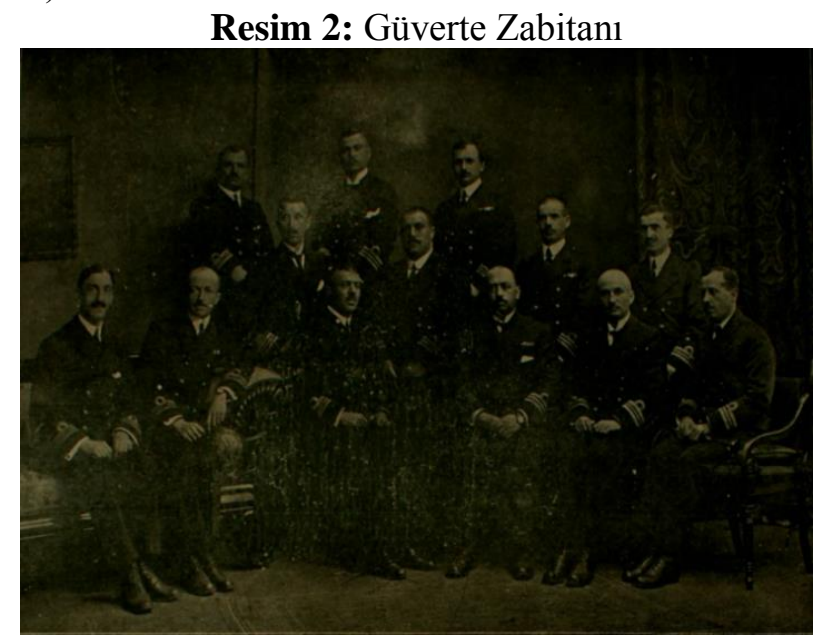

Turkish Studies - Historical Analysis

Volume 14 Issue 3, 2019 


\section{Güvertecilerin Kurslarda ve Donanmada Ders Programları}

\subsection{Torpido Zabitanına Mahsus Talim ve Eğitim}

Birinci Hafta; torpidobotların amacı ve kullanılmaları, büyük gemilerde, denizaltı ve tayyarelerdeki torpido ve silahlar

İkinci Hafta; torpido ve subayların gemilerle torpidobotlardaki hizmetleri

Üçüncü Hafta; subayların gemilerle torpidobotlardaki hizmetleri

Dördüncü Hafta; torpidobot şubesi ve teşkilatı

Beşinci Hafta; torpidobot hücumunun nazariyatı

Altıncı Hafta; yukarıdaki konuların tekrarı

Endaht Talimleri; herhangi bir sebepten dolayı endaht talimi yapılması mümkün olmazsa düşman devletlerin donanmalarında bulunması muhtemel torpido silahı ve torpidobotları konusunda bilgi verilecek ve bu konuları anlatan dersler tekrar edilecekti.

\section{2. Şuvarskof Torpidosu Kurs Programı}

Birinci Hafta; yutublar, torpido ve kullanılan cephanelere dair genel açıklamalar

İkinci Hafta; savaş başlığı, talim başlığı, müsademe tab'ası, hava hazinesi, yutuba ateş donanımı

Üçüncü Hafta; makine kısmı, makine kısmındaki boru donanımı, dayrektör, ana makine, durdurma tertibat1, valf

Dördüncü Hafta; dümen tertibat1, lion tertibatı

Beşinci Hafta; cayraskop, şaft ve kuyruk kısmı, endaht defterinin tutulması

Altınc1 Hafta; ihtiyat haftası ve hava tulumbas1

Yedinci Hafta; pasaparola emir tertibat1

On dördüncü Hafta sonuna kadar; öğrencilerin öğrendikleri derslerin tekrarı yapılacaktır

Endaht Eğitimi (DMA, BN, 236/4487)

Birinci Hafta; dayrektör

İkinci ve Üçüncü Hafta; gündüz endaht1

Dördüncü Hafta; gece endaht1

Beşinci ve On dördüncü Hafta; torpidonun geçeceği noktanın tayin edilmesi, yardımcı nişan alma durumu ve yardımcı nişan noktasının kullanılması, endaht sırasında yapılan hataların gösterilmesi

Talim Hizmeti

Birinci Hafta; yutub mürettebatının tek başına hizmetine dair ilmi ders

İkinci ve Üçüncü Hafta; basit yutub talimi ve torpidoyu yutuba sürmek talimi hazırlamak

Dördüncü Hafta; torpido üzerinde yapılan muameleyi sırasıyla yapmak, torpidobotu endahta

Beşinci Hafta; yutuba savaş arızalarıyla talim yapma

Altıncı Hafta; denizaltı yutubta talim, daha önceki talimlerin tekrarı

(Ayrıca, 5 ve 6. hafta torpido almak ve vermek ve bir mahalden başka bir mahale taşımak) 
Yedinci ve Sekizinci Hafta; torpidoyu yakalayacak araçların hizmeti ve yakalama

Dokuzuncu ve Onuncu Hafta; yukarıdaki haftalardaki konuların tekrarı

On üçüncü ve On dördüncü Hafta; endaht edilmiş torpidonun tarassudu, torpidoların bade'1 endaht batması veya tanzim dilen mesafeyi tecavüz etmesi, istikametinden inhiraf etmesi halinde alınacak tedbirler, endaht edilen torpidonun yakalanması, torpidobota torpido almak, vermek ve torpidoyu bir yerden başka bir yere taşımak (DMA, BN, 236/4487)

\subsection{Güverte Mühendislerinin Kurslarda ve Donanmada Sûret-i Tahsilleri Hakkında} Tâlimâtname

Birinci Kısım; Seyr-i sefâin (haftada beş saat); heyet-i bahriye, kronometre, irtifâ almak, pusula, ilm-i ahvâl, med-cezirdir. Mektep gemisinde takip edilen mevâd-1 tedrisiye tekrar verilerek kısmen kerteriz ile mevki-i sefine tayin etmek, münâvere mesâili perâkete hesâbâtı derece-i itimâd mufassal bir sûrette gösterilir.

İkinci Kısım; ûfki ve muâdel nehar müstevileri üzerinde kimyât ve zâiye-i semâviyenin irtisâmları beyinlerindeki münâsebet-i ûmûmiye, müselles heyet-i (kutbi) semt res, kûtûb, cürüm, muad'ül-nehâr müstevisi üzerindeki artesamati ûfki müstevisi üzerinde küstürmek, heyet-i bahriye usûlleri ile mevkii sefine, usûl-i umûmi ile mevkii hatlarının istihsâli (irtifâi usulüyle) ahvâli hûsûsiye ile mevkii hatlarının istihsâli (gârk ve tûl usûlü), bir iki yahût daha fazla pont hatlarıyla mevkii sefine tayin etmek, pont hatlarının hatası, güneș, kâmeri, ecrâm sevabete ve seyarattan alınan irtifâ' ile pont hatlarının hesâbı ve tersimi, müteâdid pont hatlarıyla mevkii sefineyi tayin etmek, (garaf kâğıdı, harita ve ve samenar diyâğramı üzerine), yevmiye jurnali ve bu husus için ecrâmın intihâbında ve âlel-husûsi zevâl rasadatı hakkında dikkat edilecek esasat-1 umûmiye, mevkii sefine tayinini teshil eden cedvel diyâğrâmları,

Üçüncü Kısım; kronometre hesâbâtı, irtifaât mütenâzır ve mütesâviye usûlleri ile kronometre hatayı umûmi ve tahâllüf yevmiyesinin tayini, kronometre hesâbâtı, irtifaat mütenâzıra ve mütesâviye usûlleri ile kronometre, hatayı umûmi ve tahâllüf yevmiyesinin tayini, kronometre hatasını bulmak

Dördüncü Kısım; mıknâtıs pusulalarda inhirâf ârzı; inhirâf ârzının vücûdunu anlamak ve miktarını hesâp etmek, sefine mıknâtısının inhirâf-1 ârziye tesiri, inhirâf ârziyi husûle getiren esbâb ve yegân yegân târifi, inhirâf ârziyenin tebdili, mıknâtisiyet

Beşinci Kısım; çayraskoplu pusulalar, çayraskobun harekâtı mihânikiyesi, çayraskop nâzâriyat1, tek harekât devriyeli pusulalar, çayraskoplu pusulaların hatası, üç hareket devriyeli pusulalar

Altıncı Kısım; ilm-i ahvâl

Yedinci Kısım; ilmi ahval-i bahri

Sekizinci Kısım; med-cezirin tarihi ve vukûa geldiği mahaller, med-cezirlerin tesiri, med-cezirin vakti ve vukuundan evvel bâ-hesâb bulmak, harita üzerinde âmik bahre aid kuyudatın med'in tesiriyle suret-i tebeddülü, med-cezir akıntıları, hususat-1 seyriyede med-cezirin ehemmiyeti

Dokuzuncu Kısım; mesâha-i bahriyeden beklenilen maksad, fenni mesâha, usulü, buna ait alet ve edevât ve bu husûsta müstahdem mesâhac1 efrâd hakkında malûmat-1 umûmiye ve yapılacak mesâha ameliyatı için malûmatı mufassala

\subsection{Güvertecilerin Seyr-i Sefain ve Kılavuzluk Kurs Programı ( 9 hafta $5 \frac{1}{1} 2$ gün toplam 44 gün)}

Seyir zâbitlerinin genel vâzifeleri bahriye kânunnâmesindeki malûmat ile geminin seyrine âit mütâlâat adındaki İngilizce risâle; 5 ำ gün 
Deniz haritaları ile rehber-i derya risâlelerinin ve harita sandıklarında bulunan kitaplar, cetveller ve diğer alet edevatın doğrudan kullanımları, geminin yerinin belirlenmesi, rota vermek, med-cezir ve akıntı tesirini hesaplamak; 5 11/2 gün

Kılavuz sularında geminin seyir esasları, rehber alâmetleri kurtarma alametleri ve tehlike zâviyeleri ve tehlikeden içtinâb için kerteriz hatlarının kullanımı, harita üzerinde daha önce hazırlanmış bir mevkii gemiyi demirlemek, demirleme diyâğrâmı, sisli havada seyir esnâsında ittihâz edilen takâyyüdât ve iskandillerin kullanılma usûlü

Mûhtelif hükümet sahillerinde kullanılmış olan deniz fenerlerinin, şamandıraların, sis işaretlerinin çeşitleri; 5 1⁄2 gün

Aleti cevriye, iskandil makinesi, uskuru, pârâkete ve diğer seyir aletlerinin doğrudan kullanımı ve idareleri; 4 gün

Admiralti medcezir cetvelleriyle atlaslarının kullanımı; 1 1⁄2 gün

Mesafe; küçük bir plan yapmak 4 gün

Kronometrelerin idareleri ve bunlara edilecek takâyyüdat, kronometrelerin istifleri ve edevat, elektrikten olan mesâfe-i salmaları, kronometrelerin mukayesesi ve bunlardan vaktin sıhhâtle âhzı, kronometrelerin mûhtelif yevmilerinin genel olarak tayini; 1 1 1/2 gün

Mıknâtısıt hakkında ilk esaslar; geminin mıknâtısıtı ve bunun tahavvüle olan istidâdı, nısfiye ve râbiye ve mil hataları ve bunların tashih mehânikiyeleri hakkındaki esâslar, bir pusulayı $\mathrm{B}, \mathrm{C}, \mathrm{D}$ emsâlleri için tashih etmek, gemiyi saldırmak ve bir inhirâf ârz cetveli düzenlemek, pusulaların idareleri, kullanılmaları ve istif edilmeleri, pusulaların elektrik malzemelerinden olan mesâfe-i salmaları hakkındaki kurallar, bir talim gemisinde geçirilecek 4 veya 5 günde dahil olduğu halde 14 gün 1909: 3)

İmtihan 2 1⁄2 gün, Toplam 44 gün (Güverte Zabitanına Mahsus Dört Umumi Kurs Programı,

\section{Sonuç}

Osmanlı Donanması için Güverte Mektepleri açılarak güverteci ihtiyacı karşılanmaya başlamıştır. Mektepte talebelere hem teorik hem de uygulamalı eğitim verilerek güvertecilerin yetiştirilmesine oldukça dikkat edilmiştir. Güverte talebeleri, mektepteki askeri terbiye ve meslekle ilgili eğitimlerine tamamlamalarından sonra mühendis olarak kabul edilmişlerdir. Avrupa devletlerinin donanmalarında denizcilerin savaş gemilerinde göreceği kullanacağı alet, araç ve gereçlerdeki değişikliklerle yeniliklere uygun bir surette umumi kurslar açılıyordu. Bu suretle donanmaya elverişli bilgi sahibi zabitan yetiştiriliyordu. Bununla beraber tahsilin mükemmel olmasıyla rütbelerine kıdem zammı gibi mükâfatlardan da istifade edebilmeleri amaçlanıyordu. Osmanlı Donanması içinde de bir süre sonra güvertecilerin bilgisini genişletmek amacıyla kurslar açılmaya başlamıştır. Özellikle Osmanlı Devleti'nin yeni satın aldığı torpidoların kullanımları hakkında güvertecilerin yetiştirilmesine büyük önem verilmiştir. Güvertecilere, bu kurslarda torpidolarla ilgili teknik bilgilerin, özellikle uygulamalı şekilde verilmesine çalışılmıştır. Bu eğitimlerin sonunda başarılı olanlar rütbe ve kıdem zammı almışlardır. Ayrıca, Osmanlı Donanması için çok önemli bir rol oynayan torpidolar, bu konuda özel olarak yetiştirilen güverteciler tarafından güvenli bir şekilde kullanılmaya başlanmıştır. 


\section{KAYNAKÇA}

\section{Arşiv Kaynakları / Archival Sources}

Deniz Müzesi Arşivi (DMA)

Bahriye Nezareti (BN), 85/171, 8 Eylül 1333 (8 Eylül 1917).

BN, 55/1053.

BN, 61/1291.

BN, 65/1291, 25 Mart 1334 (25 Mart 1918).

BN, 236/4487.

Mülga Bahriye (MB), 57/89.

MB, 517/249, 14 Haziran 1334 (14 Haziran 1918).

MB, 534/257.

III. Daire, 30/8, 30 Rebiülevvel 1331 (9 Mart 1913)

Bahriye Dairesi Riyaseti (BD.R), 118/12, 20 Zilhacce 1339 (25 Ağustos 1921)

M.M.55-31-01

\section{Basılı Kaynaklar}

Güverte Mektebi Bahriye-yi Şahanesi Öğrencisinin Suret-i Kabulü Talim ve Terbiyesi Hakkında Talimatname, Matbaa-i Bahriye, 1334 (1914).

Güverte Deniz Öğrencisinin Talim Sefinesinde Suret-i Tahsil ve Tedrisleri Hakkında Talimatname, Matbaa-i Bahriye, 1334 (1918).

Güverte Zabitanına Mahsus Dört Umumi Kurs Programı, Bahriye Matbaası, 1329 (1909).

Güverte Mühendislerinin Mekteb-i Bahriyenin Dördüncü Sınıfında Kurslarda ve Donanmada Suret-i Tahsilleri Hakkında Talimatname, Matbaa-i Bahriye, 1917.

Bahriye-i Güverte Zabitanının Suret-i Duhul ve Tahsili Hakkında Nizamname, Matbaa-i Bahriye, 1917. Güverte Deniz Talebesinin Talim Sefinesinde Suret-i Tahsil ve Tedrisleri Hakkında Talimatname, 1918.

Güverte Mühendislerinin Dördüncü Sınıfta, Kurslarda ve Donanmada Tahsilleri Hakkında Talimatname, 1917.

Gülen, N. (2001) “Şanlı Bahriye (2001). Türk Bahriyesinin İki Yüzyıllık Tarihçesi 1773-1973”, Kastaş Yayınları, İstanbul.

Gökçay, N. “Deniz İkmal Eğitimi ve Okulları 1699-1999”, Deniz Basımevi, İstanbul.

Nadir Eserler Kütüphanesi, 93430-1. 